\title{
SURGICAL SITE INFECTION SURVEILLANCE AFTER DISCHARGE FROM HOSPITAL
}

Ajay Saha1 ${ }^{1}$ Prabir Kr. Saha ${ }^{2}$

${ }^{1}$ Associate Professor, Department of Surgery, Tripura Medical College.

${ }^{2}$ Associate Professor, Department of ENT, Tripura Medical College.

\section{ABSTRACT}

\section{AIMS AND OBJECTIVES}

This study aim to determine the SSI incidence in patients after common biliary operation usually undertaken in this hospital.

\section{MATERIALS AND METHODS}

This study was undertaken with effect from March 2010-February 2015, in patients who underwent cholecystectomy, cholecystectomy+choledocholithotomy and cholecystectomy+choledocholithotomy+choledocoduodenostomy/transduodenal sphincteroplasty in the hospital, where attending patients were mostly from lower middle class and poor category. The patients were monitored from hospital admission to up to 30 days post-surgery. After the discharge from hospital patients were followed up in OPD for wound infection by the surgeon, removal of suture if any.

\section{RESULT}

The sample included 237 patients of which 67\% were female who underwent cholecystectomy, cholecystectomy +choledocholithotomy and cholecystectomy+choledocholithotomy+choledocoduodenostomy/transduodenal sphincteroplasty. Most of the patients belong to lower socioeconomic status. Patients stayed in the hospital from around 7 days or more. Post discharge $92 \%$ attended OPD for followup, which is satisfactory considering the availability and cost of public transport system. An $8 \%$ who were lost to followup were not included in the study. In this study, total 36 cases of SSI (15.1\%) were detected. Most SSIs were superficial (97\%), only $3 \%$ were deep. SSIs were common in cases of contaminated surgical procedures.

\section{CONCLUSION}

This study corroborates previous such studies in this field and indicate reliability of post discharge SSI surveillance.

\section{KEYWORDS}

Surgical Site Infection Surveillance after Discharge from Hospital.

HOW TO CITE THIS ARTICLE: Saha A, Prabir Kr. Saha. Surgical site infection surveillance after discharge from hospital. J. Evolution Med. Dent. Sci. 2016;5(8):357-358, DOI: 10.14260/jemds/2016/80

\section{INTRODUCTION}

SSI are the infection of the tissue, for which surgeon is responsible, by exposing the tissue while performing an invasive procedure. SSI is a common postoperative complication causing prolongation of sufferings, financial burden and overall dissatisfaction amongst the patients. It accounts for $14 \%-16 \%$ of nosocomial infection.(1)

Surveillance only during the period of hospitalization after the operation may underestimate the incidence of SSI.(2) This study aim to determine the SSI incidence in patients after common biliary operation usually undertaken in this hospital. The present study is based on both in hospital and post discharge surveillance.

\section{METHOD}

This study was undertaken with effect from March 2010February 2015, in patients who underwent cholecystectomy, cholecystectomy + choledocholithotomy and

Financial or Other, Competing Interest: None.

Submission 05-12-2015, Peer Review 06-12-2015,

Acceptance 16-12-2015, Published 27-01-2016.

Corresponding Author:

Dr. Ajay Saha,

Associate Professor,

Department of Surgery,

Tripura Medical College,

Hapania, Agartala-14.

E-mail: drajaysaha@yahoo.in

bgogoi123@yahoo.co.in

DOI: $10.14260 /$ jemds $/ 2016 / 80$ cholecystectomy+choledocholithotomy+choledocoduodenost omy/transduodenal sphincteroplasty in the hospital, where attending patients were mostly from lower middle class and poor category.

The patients were monitored from hospital admission to up to 30 days post-surgery. US CDC maintains that a 30 -day followup is necessary in non-prosthetic surgery and one year in which a prosthesis has been implanted. After the discharge from hospital patients were followed up in OPD for wound infection by the surgeon, removal of suture, if any.

The surgical wounds were classified into superficial (Limited to skin and subcutaneous tissue), deep and organ/space infections. (3)

The determination of SSI were based on signs of inflammation (Oedema/erythema, etc.), discharge of infected serous fluid/pus or need for drainage of serous fluid/pus.

\section{RESULT}

The sample included 237 patients of which $67 \%$ were female who underwent cholecystectomy, cholecystectomy +choledocholithotomy and cholecystectomy+ choledocholithotomy+choledocoduodenostomy/ transduodenal sphincteroplasty.

Most of the patients belong to lower socioeconomic status. Patients stayed in the hospital from around 7 days or more. Post discharge 92\% attended OPD for follow-up, which is satisfactory considering the availability and cost of public 
transport system. An $8 \%$ who were lost to follow up were not included in the study.

In this study, total 36 cases of SSI (15.1\%) were detected. Most SSIs were superficial (97\%), only 3\% were deep SSIs and no organ/space were detected. No mortality was noted.
SSIs were common in cases of contaminated surgical procedures, where duration of surgery was more than an hour and hospital stay was more than 7 days.

SSIs incidence depends on the type of operation and classified as clean, clean-contaminated, contaminated and dirty or infected.(4)

\begin{tabular}{|c|c|c|c|c|c|c|c|}
\hline Surveillance & $\begin{array}{c}\text { Surgery } \\
\text { Classification }\end{array}$ & $\begin{array}{c}\text { Post- } \\
\text { Surgery } \\
\text { Hospital } \\
\text { Stay }\end{array}$ & $\begin{array}{c}\text { Duration of } \\
\text { Surgery }\end{array}$ & $\begin{array}{c}\text { Surgical } \\
\text { Contamination }\end{array}$ & SSI Classification & $\begin{array}{l}\text { SSI } \\
\text { No. }\end{array}$ & $\%$ \\
\hline & Total SSI No. & $\begin{array}{c}7 \text { day }> \\
7 \text { day }\end{array}$ & $\begin{array}{c}\text { One hour } \\
>\text { One Hour }\end{array}$ & & & & \\
\hline In Hospital & $\begin{array}{c}C \\
1993\end{array}$ & $\begin{array}{c}\text { Total } 195 \\
42 \\
\text { SSI } 29 \\
\end{array}$ & $\begin{array}{c}1 \mathrm{hr}=2 \\
>1 \mathrm{hr} .=9\end{array}$ & Clean $=3$ & Superficial $=10$ & 11 & $4.6 \%$ \\
\hline In Hospital & $\begin{array}{c}\mathrm{C}+\mathrm{CDL} \\
326\end{array}$ & & & $\begin{array}{c}\text { Clean - } \\
\text { Contaminated }=6\end{array}$ & Deep $=1$ & & \\
\hline In Hospital & $\begin{array}{c}\mathrm{C}+\mathrm{CDL}+\mathrm{D} \\
\quad 62\end{array}$ & & & Contaminated $=2$ & $\begin{array}{c}\text { Organ/Space } \\
\text { infection }=0\end{array}$ & & \\
\hline $\begin{array}{c}\text { Post } \\
\text { Discharge }\end{array}$ & $\begin{array}{c}\mathrm{C} \\
19912\end{array}$ & $\begin{array}{c}\text { Total } 195 \\
42 \\
\text { SSI } 916\end{array}$ & & Clean $=12$ & Superficial $=10$ & 25 & $10.5 \%$ \\
\hline $\begin{array}{c}\text { Post } \\
\text { Discharge }\end{array}$ & $\begin{array}{c}\mathrm{C}+\mathrm{CDL} \\
3210\end{array}$ & & $\begin{array}{c}1 \mathrm{hr} .=9 \\
>1 \mathrm{hr} .=16\end{array}$ & $\begin{array}{c}\text { Clean - } \\
\text { Contaminated }=10\end{array}$ & Deep $=0$ & & \\
\hline $\begin{array}{c}\text { Post } \\
\text { Discharge }\end{array}$ & $\begin{array}{c}\mathrm{C}+\mathrm{CDL}+\mathrm{D} \\
63\end{array}$ & & & Contaminated $=3$ & $\begin{array}{c}\text { Organ/Space } \\
\text { infection= } 0\end{array}$ & & \\
\hline TOTAL & & & & & & 36 & $15 \%$ \\
\hline
\end{tabular}

\section{DISCUSSION}

The result of this study corroborates other studies done earlier, suggesting that the major bulk of SSIs occur post discharge.(5) The surveillance during the period of hospitalization only do not reflect exact SSI rate. This study suggest the need for post discharge surveillance, so as not to underestimate the magnitude of SSIs, though most of the SSIs were superficial.

This post discharge surveillance appears to have good patient compliance, effective to a great extent and cost effective.

\section{CONCLUSION}

This study corroborates previous such studies in this field and indicate reliability of post discharge SSI surveillance.

\section{ABBREVIATIONS USED}

Surgical Site Infection= SSI

Cholecystectomy $=\mathrm{C}$

Cholecystectomy + Choledocholithotomy $=\mathrm{C}+\mathrm{CDL}$

Cholecystectomy+Choledocholithotomy+Choledocoduodenos tomy/Transduodenal Sphincteroplasty $=\mathrm{C}+\mathrm{CDL}+\mathrm{D}$

\section{REFERENCES}

1. Mangram AJ, Horan TC. Guideline for prevention of surgical site infection. University of Minnesota, Minneapolis. Infection Control Hosp. Epidemiol-1999; 20:247-80.

2. Delgado-Rodriguez M, et al. Epidemiology of surgical site infections diagnosed after hospital discharge: a prospective cohort study. Infection Control Hospital Epidemiol 2001; 22(1):24-30.

3. Alexander JW, et al. Updated recommendations for control of surgical site infections. Ann Surg 2011; 253(6):1082-1093.

4. Harold Ellis, et al. Lecture Notes: General surgery $12^{\text {th }}$ edition 2011. West Sussex, UK. Wiley Blackwell publishing. Postoperative complications 15-25.4\%.

5. Holtz TH, et al. Post discharge surveillance for nosocomial wound infection: a brief review and commentary. Am J Infect control 1992; 20:206-13. 